\title{
Diseminasi Teknologi True Seed of Shallot dan Umbi Mini Bawang Merah di Karangploso, Malang, Jawa Timur
}

\section{(Technology Dissemination of True Seed of Shallot and Mini Shallot Bulbs in Karangploso, Malang, East Java)}

\author{
Makhziah*, Ida Retno Moeljani, Juli Santoso \\ Program Studi Agroteknologi, Fakultas Pertanian, Universitas Pembengunan Nasional "Veteran” Jawa Timur, \\ Jl. Raya Rungkut Madya-Gunung Anyar Surabaya 60294 \\ *Penulis Korespondensi: makhziah.agro@upnjatim.ac.id \\ Diterima Oktober 2018/Disetujui April 2019
}

\begin{abstract}
ABSTRAK
Bawang merah (Allium cepa var. aggregatum) merupakan salah satu komoditas sayuran yang kebutuhannya terus meningkat sejalan dengan pertambahan jumlah penduduk. Tujuan kegiatan pengabdian masyarakat ini adalah diseminasi hasil penelitian cara memproduksi biji bawang merah true seed of shallot (TSS) kemudian menanam benih TSS untuk menghasilkan umbi mini sebagai benih bawang merah. Partisipan yang menjadi khalayak sasaran adalah kelompok tani "Tani Mulya" Desa Tawangargo, Kecamatan Karangploso, Kabupaten Malang, Jawa Timur. Tahapan kegiatan meliputi persiapan kegiatan, sosialisasi kegiatan, demo plot penanaman umbi bawang merah untuk menghasilkan benih TSS, dan penanaman benih TSS untuk menghasilkan umbi mini sebagai benih bawang merah. Varietas Batu Ijo ditanam untuk menghasilkan benih TSS, sedangkan penanaman benih TSS menggunakan varietas Tri Sula dan Keta Monca. Kegiatan berjalan dengan baik menurut skala Likert sebesar 4,3 (kategori baik= 4-4,9). Petani mampu mengadopsi teknologi produksi TSS dan penanaman benih TSS untuk menghasilkan umbi mini sebagai benih tanaman bawang merah dengan indikasi dihasilkannya benih TSS dan umbi mini. Tanaman bawang merah yang berbunga sebesar $55,5 \%$ dan bobot biji TSS yang dihasilkan adalah $10,16 \mathrm{~g} / \mathrm{m}^{2}$. Benih dari umbi pada varietas Batu Ijo menghasilkan umbi yang besar, sedangkan benih TSS dari varietas Tri Sula dan Keta Monca menghasilkan umbi mini yang dapat digunakan sebagai bibit bawang merah. Peralihan teknologi pengunaan benih bawang merah dari umbi menjadi benih TSS akan menguntungkan secara ekonomi karena kebutuhan benih bawang merah TSS lebih sedikit dibandingkan dengan benih umbi sehingga selisih biaya cukup besar. Kebutuhan TSS adalah sebanyak 3-5 kg/ha (harga TSS Rp 1.200.000/kg), sedangkan kebutuhan benih umbi sebesar 1-1,5 ton/ha (harga benih umbi Rp 30.000/kg) atau selisihnya Rp 24.000 .000 .
\end{abstract}

Kata kunci: bawang merah, teknologi diseminasi, true seed of shallot, umbi mini

\begin{abstract}
Shallots (Allium cepa var. aggregatum) is one of the vegetable commodities whose demand continues to increase in line with population growth. The purpose of this community service program to disseminate the results of research on how to produce true seed of shallot (TSS) then plant TSS to produce mini bulbs as seeds of shallots. The target audience was the farmers group Tani Mulya in Tawangargo Village, Karangploso SubDistrict, Malang Regency, East Java. Activities step included preparation, socialization, demonstration plot of shallot bulbs planting to produce TSS and planting TSS, to produce mini bulbs as seeds of shallot. Batu Ijo variety grown to produce TSS, while planting of TSS used Tri Sula and Keta Monca varieties. This activitity was done well according to a Likert scale of 4.3 (good category $=4-4.9$ ). Farmers were able to adopt the technology of TSS production and planting of TSS to produce shallot mini bulbs of seeds, with indication of the production of TSS and mini bulbs. The flowering of shallot plants $55.5 \%$ and TSS seed weight $10.16 \mathrm{~g} / \mathrm{m} 2$. Bulbs seed of Batu Ijo variety produced large bulbs, while TSS from Tri Sula and Keta Monca varieties produced mini bulbs that can be used as seeds. The change of the shallot seeds technology from bulbs to TSS will be economically beneficial, because the TSS required less than bulbs, so the cost difference is quite large. TSS needs $3-5 \mathrm{~kg} / \mathrm{ha}$ (TSS price IDR $1.200 .000 / \mathrm{kg}$ ), and bulbs seed needs $1-1.5$ ton/ha (bulbs price IDR $30.000 / \mathrm{kg}$ ), so the margin is IDR 24.000.000 per hectare.
\end{abstract}

Keywords: mini bulbs, shallots, technology dissemination, true seed of shallot 


\section{PENDAHULUAN}

Bawang merah merupakan salah satu komoditas sayuran unggulan yang sejak lama telah diusahakan oleh petani secara intensif di Indonesia. Komoditas sayuran ini termasuk ke dalam kelompok rempah tidak bersubstitusi yang berfungsi sebagai bumbu penyedap makanan serta obat tradisional. Permintaan akan bawang merah terus meningkat sejalan dengan peningkatan jumlah penduduk (Pusat Data dan Informasi Pertanian 2015). Beberapa daerah di Indonesia merupakan sentra produksi bawang merah seperti di Brebes, Nganjuk, Kendal, Pati, Solok, Majalengka, Probolinggo, Pare-Kediri, dan Malang (Pusat Data dan Informasi Pertanian 2015).

Salah satu kendala utama yang dihadapi dalam usaha peningkatan produksi bawang merah saat ini adalah terbatasnya ketersediaan benih bawang merah bermutu. Kekurangan benih bermutu dipenuhi dengan penggunaan umbi konsumsi sebagai benih atau menggunakan umbi impor. Hal ini akan mengurangi jumlah produksi bawang merah konsumsi. Penggunaan umbi sebagai bibit secara terus menerus oleh petani dapat menurunkan kualitas bibit akibat akumulasi patogen tular umbi termasuk virus yang akan berdampak pada menurunnya produktivitas tanaman. Oleh sebab itu, perlu terobosan teknologi dengan memproduksi biji bawang merah sebagai bahan tanam atau yang disebut biji true seed of shallot (TSS).

Hasil penelitian Moeljani (2015) telah mampu menghasilkan biji bawang merah melalui pembungaan dengan cara penambahan lama penyinaran (lampu TL). Menurut Suwandi (2013) secara alami bawang merah di Indonesia dapat menghasilkan bunga dan biji TSS, kecuali varietas Sumenep. Keberhasilan produksi biji TSS dipengaruhi oleh varietas, fisiologi umbi bibit, ketepatan budi daya, iklim setempat, sedangkan vernalisasi (pendinginan umbi pada suhu $10^{\circ} \mathrm{C}$ selama beberapa minggu) dan aplikasi ZPT $\left(\mathrm{GA}_{3}\right)$ merupakan kunci utama pembungaan bawang merah (Suwandi 2013).

Oleh karena itu inovasi teknologi pembungaan pada bawang merah ini harus disosialisasikan dan didesiminasikan kepada petani bawang merah agar mereka bisa menghasilkan biji TSS dan menanamnya untuk menghasilkan bibit bawang merah yang unggul. Keunggulan TSS adalah meningkatkan hasil umbi bawang merah sampai dua kali lipat dibandingkan dengan penggunaan benih umbi (produksi 26 ton/ha), bebas dari penyakit dan virus, dan harga biji TSS lebih murah 10 kali lipat dibandingkan dengan umbi, dan daya simpan lebih lama (Litbang Pertanian 2015).

Salah satu daerah penghasil bawang merah di Jawa Timur adalah Desa Tawangargo, Kecamatan Karang Ploso, Kabupaten Malang. Varietas bawang merah yang ditanam di daerah tersebut adalah Batu Ijo yang secara alami dapat menghasilkan biji TSS, namun petani setempat masih menggunakan benih umbi (Harian Surya Malang 2017). Masalah utama dalam teknologi biji TSS di tingkat petani adalah kendala transisi adaptasi teknik budi daya bawang merah dari penggunaan bibit umbi yang relatif mudah beralih ke benih TSS yang perlu ketekunan pemeliharaan terutama di awal pertumbuhan (Prayudi et al. 2015). Oleh sebab itu, benih TSS digunakan untuk menghasilkan umbi mini (ukuran umbi kecil \pm 3 g) dan selanjutnya umbi mini digunakan sebagai benih bawang merah untuk memproduksi bawang merah konsumsi.

Tim pengabdian masyarakat yang sudah meneliti dan membuat kajian teknik memproduksi biji bawang merah TSS dan berhasil menumbuhkan biji TSS menjadi tanaman serta menghasilkan umbi mini akan melakukan diseminasi dan aplikasi teknologi tersebut ke masyarakat petani. Tujuan kegiatan pengabdian masyarakat ini adalah transfer teknologi untuk memproduksi benih bawang merah (TSS) dan umbi mini sebagai benih kepada petani bawang merah di daerah Karangploso, Kabupaten Malang sebagai salah satu sentra produksi bawang merah di Jawa Timur.

\section{METODE PELAKSANAAN KEGIATAN}

\section{Lokasi dan Partisipan Kegiatan}

Kegiatan ini dilakukan di Desa Tawangargo, Kecamatan Karangploso, Kabupaten Malang, Jawa Timur pada bulan April-Oktober 2018. Partisipan merupakan kelompok petani "Tani Mulya", yang mengusahakan tanaman sayuran terutama tanaman bawang merah.

\section{Bahan dan Alat}

Bahan yang digunakan adalah umbi bawang merah varietas Batu Ijo, Tri Sula, dan Keta Monca. $\mathrm{GA}_{3}$ teknis digunakan untuk memacu pembungaan tanaman bawang merah. Sarana produksi yang lain adalah pupuk kandang, dolomit, pupuk NPK (16:16:16), fungisida (dengan bahan aktif mancozeb), wadah 
penyemaian, plastik, dan tiang plastik untuk tempat penyemaian.

\section{Metode Pelaksanaan Kegiatan \\ - Pra kegiatan dan survei lokasi}

Tim melakukan survei ke daerah sentra produksi bawang merah di Karangploso, Kabupaten Malang sebagai partisipan kegiatan pengabdian masyarakat. Tim juga melakukan persiapan kegiatan berupa perlakuan pendahuluan, yaitu vernalisasi (perlakuan pendinginan) umbi selama 7 hari dengan cara umbi disimpan di dalam lemari pendingin (kulkas) pada suhu $5-7^{\circ} \mathrm{C}$ dan perendaman umbi bawang merah dalam larutan $150 \mathrm{ppm} \mathrm{GA}_{3}$ selama 30 menit untuk memacu pertumbuhan dan pembungaan tanaman bawang merah serta memproduksi biji TSS. Vernalisasi dilakukan di laboratorium Produksi Fakultas Pertanian, UPN Veteran Jawa Timur, kemudian umbi bawang merah ditanam di dalam polybag dan diletakkan di kebun percobaan. Tanaman bawang merah disiram, dipupuk NPK sebanyak 1 g tiap minggu sampai 6 minggu, dan disemprot $\mathrm{GA}_{3}$ (tiap 15 hari) sebanyak 4 kali sampai tanaman berbunga dan menghasilkan biji. Biji yang sudah masak dipanen pada umur 90 hari kemudian TSS dijemur selama 5 hari sampai kering. Benih TSS ini adalah yang disiapkan untuk kegiatan transfer teknologi pembentukan biji TSS dan pembentukan umbi mini.

\section{- Sosialisasi dan penyuluhan kegiatan pada petani Tawangargo}

Tim pengabdian masyarakat dari UPN Veteran Jawa Timur melakukan sosialisasi dalam bentuk penyuluhan tentang teknologi produksi TSS dan umbi mini bawang merah kepada kelompok tani "Tani Mulya" di Desa Tawangargo, Kecamatan Karangploso, Kabupaten Malang.

\section{- Demo plot produksi biji TSS dan umbi mini bawang merah di lahan petani}

Pertama, penanaman umbi bawang merah untuk produksi bunga dan biji TSS. Kegiatan dilanjutkan dengan demo plot penanaman umbi bawang merah di lahan milik kelompok tani "Tani Mulya" dan varietas yang digunakan adalah varietas Batu Ijo yang merupakan varietas lokal Karangploso yang biasa ditanam oleh para petani setempat. Petani juga diajarkan perlakuan untuk memacu pembungaan tanaman umbi bawang merah berupa vernalisasi umbi selama 7-10 hari (umbi dimasukkan ke dalam kulkas pada suhu 5$7^{\circ} \mathrm{C}$ ) dilanjutkan perendaman larutan $150 \mathrm{ppm}$ $\mathrm{GA}_{3}$ selama 30 menit sebelum umbi ditanam.
Kedua, penyemaian benih TSS. Pada demoplot juga dilakukan penyemaian benih TSS baik penyemaian langsung ke lahan, maupun penyemaian tidak langsung, yaitu dengan bak semai. Penyemaian langsung ke lahan memerlukan tempat semai yang ditutup plastik selama 7 hari kemudian plastik dibuka setengah.

Ketiga, pemantauan dan pengambilan data. Pemantauan dan pendampingan dilakukan oleh tim pengabdian masyarakat selama proses menumbuhkan umbi bawang merah dan biji TSS sampai waktu panen. Selama 4 bulan tim memantau pertumbuhan tanaman bawang merah yang berasal dari umbi dan biji TSS. Untuk mengetahui keberhasilan transfer teknologi produksi biji TSS dan pembentukan umbi mini, maka dilakukan pengambilan data pertumbuhan dan produksi tanaman bawang merah. Dihitung juga analisis keuntungan penggunaan benih TSS sebagai bahan tanam bawang merah dibandingkan dengan penggunaan umbi sebagai bahan tanam bawang merah.

\section{HASIL DAN PEMBAHASAN}

\section{Sosialisasi Program Kegiatan Pengabdian Masyarakat}

Tim pengabdian masyarakat melakukan kegiatan sosialisasi tentang teknologi pembungaan bawang merah dan pembentukan biji TSS serta pembentukan umbi mini bawang merah kepada khalayak sasaran, yaitu kelompok tani "Tani Mulya" yang berada di Kecamatan Tawangargo, Kabupaten Malang, Provinsi Jawa Timur. Kurang lebih sebanyak 20 orang petani mengikuti kegiatan sosialisasi teknologi pembungaan bawang merah dan pembentukan umbi mini yang bertempat di gazebo dekat lahan petani Tani Mulya (Gambar 1). Petani dijelaskan teknik vernalisasi (disimpan pada suhu dingin 5-

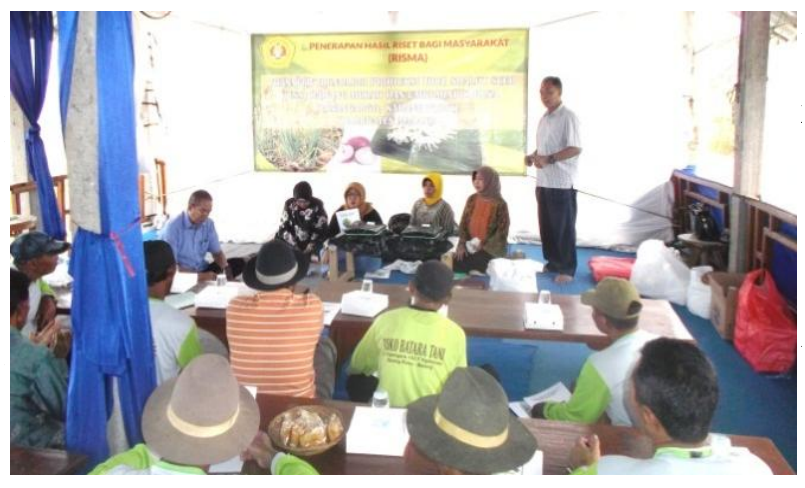

Gambar 1 Sosialisasi teknik memproduksi biji true seed of shallot umbi mini kepada kelompok tani Tani Mulya Desa Tawangargo. 
(kadar air $\pm 80 \%$ ), suhu ruang penyimpanan berkisar $30-33^{\circ} \mathrm{C}$, dan kelembapan nisbi udara berkisar $75-80 \%$.

\section{Demo Plot Penerapan Teknologi TSS}

Selesai sosialisasi dilanjutkan dengan kegiatan demo plot berupa penanaman bawang merah untuk pembungaan dan produksi biji TSS dan sekaligus penanaman biji TSS.

\section{- Penanaman bawang merah untuk produksi biji TSS}

Penanaman bawang merah dilakukan di lahan milik Desa Tawangargo yang dikelola oleh kelompok tani Tani Mulya (Gambar 2). Umbi bawang merah divernalisasi (5-10 hari sebelum penanaman) dan direndam dengan larutan 150 ppm GA (Grow Quick) selama 30 menit sebelum ditanam. Lahan sebelumnya digemburkan dan dibuat bedengan kemudian diberi campuran dolomit dan kompos. Bawang merah ditanam dengan jarak tanam $20 \times 15 \mathrm{~cm}$ atau sebanyak 25 tanaman $/ \mathrm{m}^{2}$. Pupuk NPK $200 \mathrm{~kg} /$ ha diberikan $1 / 3$ di awal tanam, $1 / 3$ umur 15 hari, dan $1 / 3$ umur 30 hari. Selesai penanaman petani diminta untuk tetap memelihara tanaman bawang merah sampai berbunga, berbiji dan panen. Penyemprotan larutan 100 ppm $\mathrm{GA}_{3}$ atau mengambil 1 $\mathrm{mL} \mathrm{GA}_{3}$ untuk $10 \mathrm{~L}$ air dilakukan setiap 15 hari sekali sebanyak 4 kali dengan volume sebesar $250 \mathrm{~mL} / \mathrm{m}^{2}$.

\section{- Penanaman benih TSS untuk produksi umbi mini}

Biji TSS ada yang ditumbuhkan dalam bak semai plastik (Gambar 3a) dan ada yang langsung disemaikan langsung di lapang (Gambar 3b) yang diberi sungkup pelindung setengah lingkaran terbuat dari plastik transparan (Gambar 3c). TSS yang disemaikan dalam bak semai adalah varietas Keta Monca, sedangkan yang ditanam langsung adalah Tri Sula dan Keta Monca.

Setelah umur 7 hari biji berkecambah dan sungkup plastik dibuka setengah sampai umur 4 minggu. Setelah biji tumbuh dan kelihatan tegar, sungkup (pelindung) plastik dibuka semua agar tanaman bisa tumbuh dengan baik.

\section{- Pemantauan dan pengambilan data}

Selama kegiatan berlangsung, tim pelaksana kegiatan pengabdian masyarakat memantau pertumbuhan dan perkembangan tanaman bawang merah untuk produksi TSS dan pembentukan umbi mini yang berasal dari TSS. Umbi yang ditanam sebanyak $25 / \mathrm{m}^{2}$, yang tumbuh dengan baik menjadi tanaman sekitar 99,31\% (24 tanaman $/ \mathrm{m}^{2}$ ) untuk varietas Batu Ijo, sementara itu yang berasal dari TSS dapat

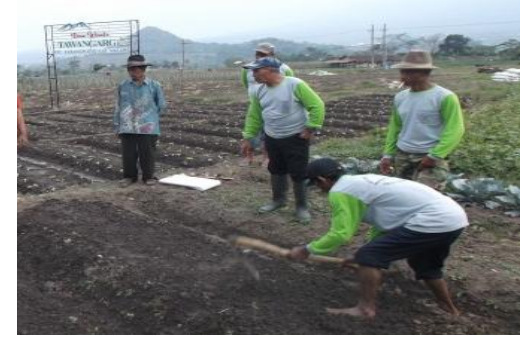

a

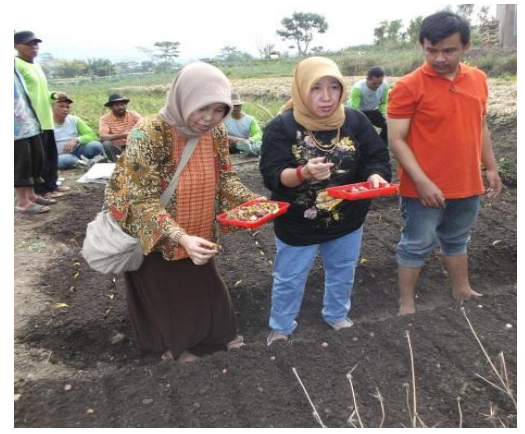

b

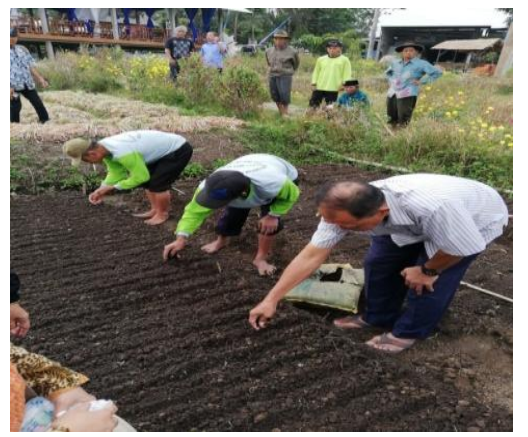

Gambar 2 a) Pembuatan larikan untuk penanaman umbi bawang merah; b) Penanaman bawang merah yang berasal dari umbi; dan c) Penanaman dari benih true seed of shallot.

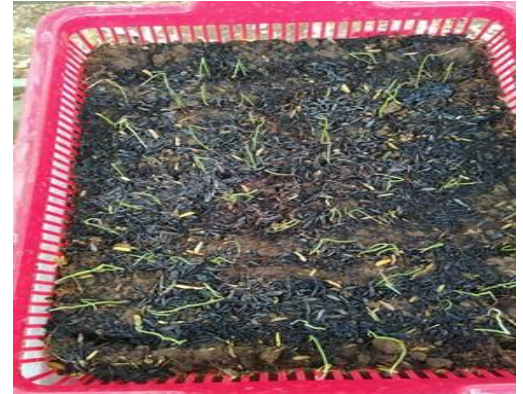

a

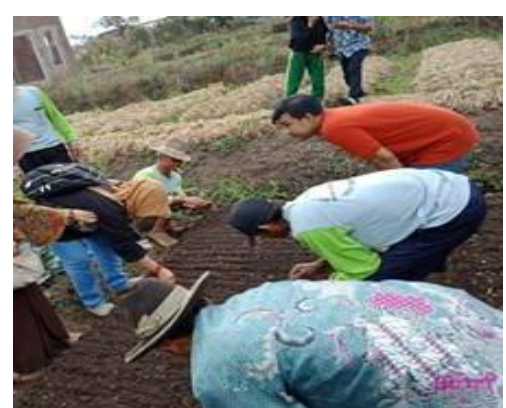

$\mathrm{b}$

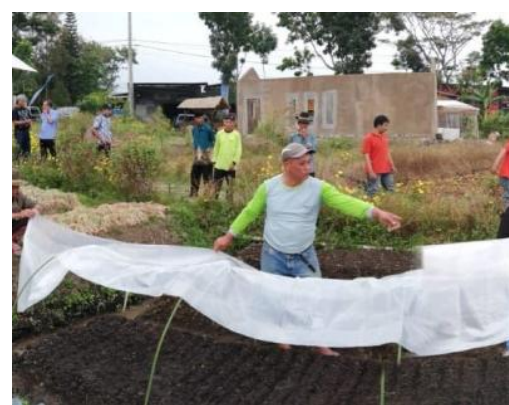

Gambar 3 a) Persemaian biji true seed of shallot dalam bak perkecambahan; b dan c) Persemaian langsung di lapang. 
tumbuh $98,32 \%$ (24 tanaman $/ \mathrm{m}^{2}$ ) pada varietas Tri Sula dan 70,23\% (17 tanaman $/ \mathrm{m}^{2}$ ) varietas Keta Monca (Tabel 1). Hasil pengamatan pertumbuhan tanaman bawang merah varietas Batu Ijo (umbi), Tri Sula (TSS), dan Keta Monca (TSS) untuk tinggi tanaman dan jumlah daun per rumpun seperti yang terlihat pada Tabel 1 . Pertumbuhan tanaman bawang merah, bunga, dan biji TSS dapat dilihat pada Gambar 4 .

Proses pembungaan pada varietas Batu Ijo menghasilkan bunga sebesar 55,5\% (dari 25 umbi $/ \mathrm{m}^{2}$ ). Setiap rumpun menghasilkan 3,94 umbel dan tiap $1 \mathrm{~m}^{2}$ menghasilkan 54,6 umbel (Tabel 2). Tiap umbel menghasilkan 120,33 bunga dan biji TSS yang dihasilkan sekitar 10,16 $\mathrm{g} / \mathrm{m}^{2}$ (Tabel 2). Benih yang berasal dari umbi (varietas Batu Ijo) menghasilkan 10,31 umbi/ rumpun, sementara itu yang berasal dari biji TSS menghasilkan 12,93 dan 12,51 umbi/rumpun untuk varietas Tri Sula dan Keta Monca (Tabel 3). Ukuran umbi hasil panen tanaman bawang merah varietas Batu Ijo (bibit umbi) lebih besar dibandingkan dengan umbi Tri Sula (benih TSS) dan Kenta Monca (bibit TSS) mempunyai ukuran umbi yang paling kecil (Gambar 5). Bobot umbi per meter persegi paling besar dihasilkan oleh varietas Batu Ijo (benih umbi) dibandingkan dengan Tri Sula (benih TSS) dan Kenta Monca (benih TSS) (Tabel 2). Menurut petani, bawang merah varietas Batu Ijo mempunyai rasa yang enak dan disukai masyarakat. Varietas Batu Ijo mempunyai umbi yang tergolong besar, yaitu 5,89 g/umbi. Umbi yang dihasilkan dari bibit TSS baik pada varietas Tri Sula maupun Kenta Monca mempunyai ukuran yang relatif kecil $(4,3$ dan $3,24 \mathrm{~g} / \mathrm{umbi}$ ) atau disebut umbi mini dan cocok untuk dijadikan sebagai benih bawang merah.

\section{Pembahasan}

Target kegiatan pengabdian masyarakat berupa transfer teknologi untuk menghasilkan benih TSS dan penanaman TSS untuk memperoleh umbi mini mendapat respons yang cukup baik dari kelompok tani Tani Mulya Desa Tawangargo, Kecamatan Karangploso, Kabupaten Malang. Menurut hasil survei dengan skala Likert untuk tingkat kepuasan mitra kelompok tani Tani Mulya terhadap kegiatan pengabdian masyarakat ini mempunyai nilai sebesar 4,3 yang berarti termasuk kategori baik (baik: 4-4,9).

Tabel 1 Pertumbuhan bawang merah (Allium cepa) dari sumber bibit umbi varietas Batu Ijo serta biji true seed of shallot pada varietas Tri Sula dan Keta Monca pada umur 2,5 bulan

\begin{tabular}{lccc}
\hline \multicolumn{1}{c}{ Sumber bibit } & $\begin{array}{c}\text { Tanaman hidup } \\
(\%)\end{array}$ & $\begin{array}{c}\text { Tinggi tanaman } \\
(\mathrm{cm})\end{array}$ & $\begin{array}{c}\text { Jumlah daun/rumpun } \\
\text { (helai) }\end{array}$ \\
\hline Umbi (varietas Batu Ijo) & 99,31 & 58,69 & 20,69 \\
Biji TSS (varietas Tri Sula) & 98,32 & 55,93 & 17,93 \\
Biji TSS (varietas Keta Monca) & 70,23 & 40,72 & 16,85 \\
\hline
\end{tabular}

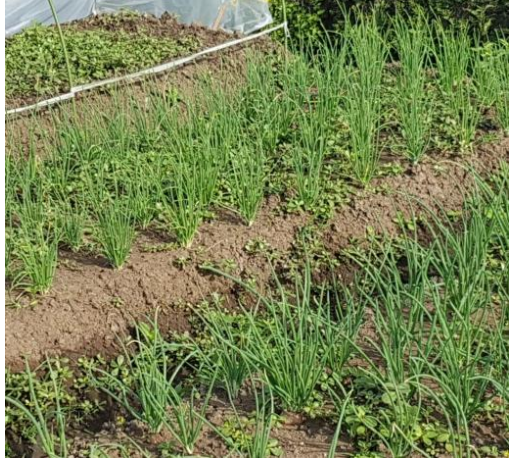

a

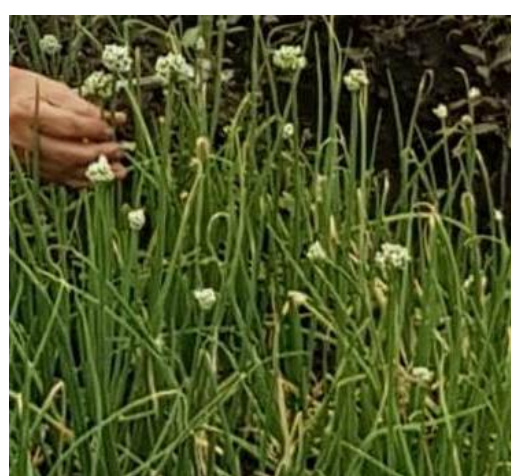

b

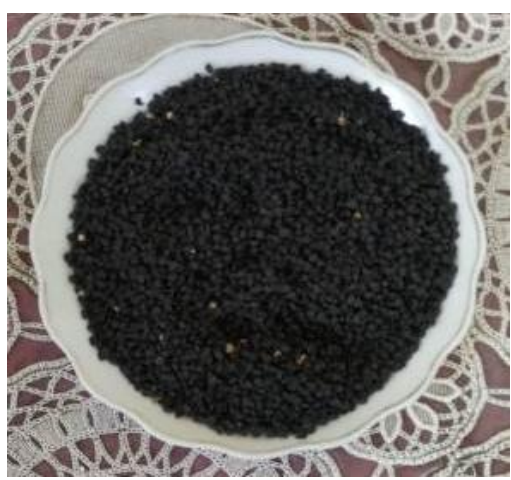

C

Gambar 4 a) Pertumbuhan tanaman bawang merah; b) Bunga bawang merah yang terbentuk; dan c) Benih true seed of shallot yang dihasilkan dari tanaman bawang merah.

Tabel 2 Rerata Jumlah umbel, jumlah bunga, dan bobot biji true seed of shallot dari bibit umbi bawang merah (Allium cepa) varietas Batu Ijo pada umur 2 bulan

\begin{tabular}{cccccc}
\hline Sumber bibit & $\begin{array}{c}\text { Jumlah tanaman } \\
\text { berbunga } / \mathrm{m}^{2}\end{array}$ & $\begin{array}{c}\text { Jumlah } \\
\text { umbel/rumpun }\end{array}$ & $\begin{array}{c}\text { Jumlah } \\
\text { umbel } / \mathrm{m}^{2}\end{array}$ & $\begin{array}{c}\text { Jumlah } \\
\text { bunga/umbel }\end{array}$ & $\begin{array}{c}\text { Berat } \\
\mathrm{biji} / \mathrm{m}^{2}(\mathrm{~g})\end{array}$ \\
\hline Umbi varietas Batu Ijo & $13,875(55,5 \%)$ & 3,94 & 54,60 & 120,23 & 10,16 \\
\hline
\end{tabular}


Tabel 3 Rerata hasil umbi tanaman bawang merah yang berasal dari bibit umbi varietas Batu Ijo serta dan biji true seed of shallot varietas Tri Sula dan Keta Monca pada umur 2 bulan

\begin{tabular}{lcccc}
\hline \multicolumn{1}{c}{ Sumber bibit } & $\begin{array}{c}\text { Jumlah } \\
\text { umbi/rumpun }\end{array}$ & $\begin{array}{c}\text { Bobot } \\
\text { umbi/rumpun }(\mathrm{g})\end{array}$ & $\begin{array}{c}\text { Bobot tiap umbi } \\
(\mathrm{g})\end{array}$ & $\begin{array}{c}\text { Bobot } \\
\text { umbi/m }(\mathrm{g})\end{array}$ \\
\hline Umbi (varietas Batu Ijo) & 10,31 & 60,73 & 5,89 & 1518,30 \\
Biji TSS (varietas Tri Sula) & 12,93 & 55,60 & 4,30 & 1390,00 \\
Biji TSS (varietas Keta Monca) & 12,51 & 40,53 & 3.24 & 1013,30 \\
\hline
\end{tabular}

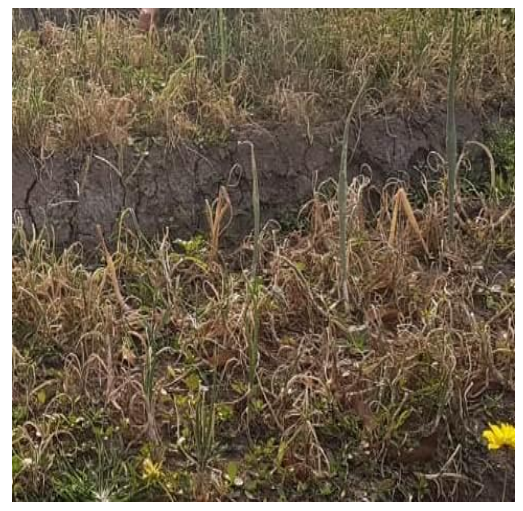

a

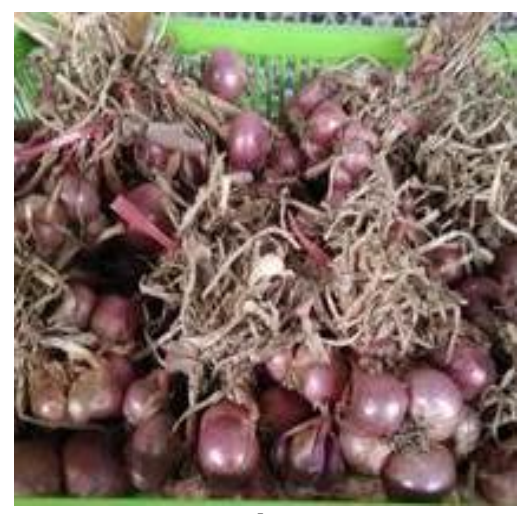

b

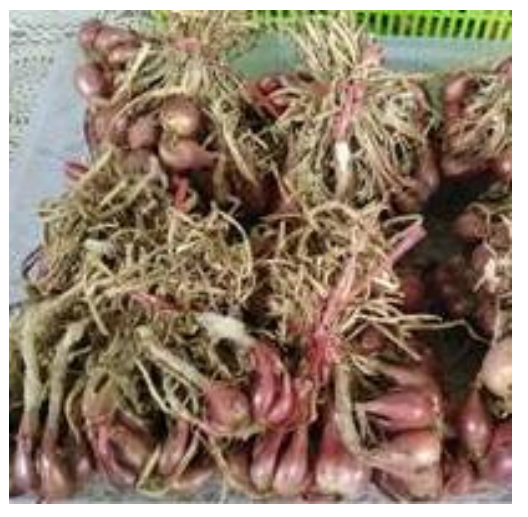

C

Gambar 5 a) Tanaman bawang merah siap panen; b) Umbi bawang merah hasil panen dari benih umbi; dan c) Umbi mini dari benih true seed of shallot.

Sebelumnya kelompok tani Tani Mulya belum pernah mencoba memproduksi biji TSS dan budi daya tanaman bawang merah yang berasal dari benih TSS, sehingga tanggapan dan minat petani pada kegiatan transfer teknologi produksi TSS dan cara budi daya bawang merah dari TSS ini baik (nilai 4,3 skala Likert).

Kelompok tani Tani Mulya Desa Tawangargo berhasil memproduksi bunga dan biji TSS dari varietas Batu Ijo yang dipraktikkan. Varietas Batu Ijo merupakan varietas lokal yang sudah ditanam di daerah Batu Malang dan sekitarnya sejak puluhan tahun dan merupakan varietas yang cocok untuk dataran tinggi dan medium, namun juga cocok di dataran rendah (Baswarsiati, 2009). Jumlah tanaman bawang merah varietas Batu Ijo yang menghasilkan bunga sebesar $55,5 \%$ $\left(13,875\right.$ dari 25 tanaman $\left./ \mathrm{m}^{2}\right)$ merupakan persentase yang cukup baik. Dilaporkan oleh Suwandi (2013) bahwa tanaman bawang merah yang berbunga sebesar $13-45 \%$, sementara itu varietas Tri Sula menghasilkan bunga sebanyak $75 \%$ pada umur 6 minggu (Prahardini \& Sudaryono 2018) dan varietas Bima Brebes sebesar 20,6-41,0\% (Palupi et al. 2017). Menurut Idhan et al. (2015) jumlah tanaman yang berbunga tergantung varietas bawang merah, di mana dari 14 varietas yang dicoba jumlah tanaman berbunga sangat bervariasi. Perlu dilakukan kajian bagaimana upaya meningkatkan persentase tanaman bawang merah berbunga untuk varietas Batu Ijo, misalnya dengan perlakuan $\mathrm{GA}_{3}$ dan paklobutrazol untuk memacu pembungaan.

Potensi Desa Tawangargo menghasilkan benih TSS cukup baik mengingat kondisi lingkungan dan faktor iklim yang mendukung untuk budi daya tanaman bawang merah TSS. Kecamatan Karangploso mempunyai ketinggian tempat $700-1000 \mathrm{mdpl}$, suhu berkisar $17^{\circ} \mathrm{C}-$ $29^{\circ} \mathrm{C}$, curah hujan $250 \mathrm{~mm} /$ tahun dan kelembapan udara 9-99\%. Kebun Percobaan Gurgur milik Pusat Penelitian dan Pengembangan Hortikultura, Kementrian pertanian yang terletak di Kabupaten Tobasa, Sumatera Utara yang mempunyai kondisi iklim hampir sama dengan Desa Tawangargo telah berhasil memproduksi benih TSS dengan sangat baik, yaitu menghasilkan $300 \mathrm{~kg} / \mathrm{ha}$ (Pusat Penelitian dan Pengembangan Hortikultura 2016).

Produksi benih TSS yang dicapai oleh petani Tawangargo masih harus ditingkatkan, karena pada hasil demo plot hanya menghasilkan benih TSS 10,16 g/ $\mathrm{m}^{2}$ atau setara dengan $101,6 \mathrm{~kg} / \mathrm{ha}$, sementara itu Kebun Percobaan Gurgur mampu menghasilkan benih TSS sebesar $300 \mathrm{~kg} / \mathrm{ha}$. Penelitian Sumarni et al. (2013) menghasilkan biji TSS sebesar $14,4 \mathrm{~g} / \mathrm{m}^{2}$ pada varietas Pancasona dan sebesar $9,67 \mathrm{~g} / \mathrm{m}^{2}$ pada varietas Mentes. Masih rendahnya jumlah tanaman berbunga pada varietas Batu Ijo, menjadi perhatian khusus untuk membuat kajian upaya meningkatkan pembungaannya. 
Manfaat dari hasil kegiatan pengabdian masyarakat ini adalah selain dapat memenuhi kebutuhan sendiri akan bibit bawang merah dari benih TSS, petani juga dapat merintis usaha menjadi seorang penangkar benih bawang merah yang benihnya lebih baik mutu dan hasilnya dan dapat menjual benih umbi mini kepada petani lain. Peralihan teknologi pengunaan benih bawang merah dari umbi menjadi benih TSS akan menguntungkan secara ekonomi karena kebutuhan benih bawang merah TSS lebih sedikit dibandingkan dengan benih umbi dengan selisih biaya cukup besar. Kebutuhan TSS adalah sebesar 3-5 kg/ha (harga TSS Rp 1.200.000/kg), sedangkan kebutuhan benih umbi sebesar 1-1,5 ton/ha (harga benih umbi Rp 30.000/kg), atau selisih (Rp 30.000.000 dikurangi Rp 6.000.000) sebesar Rp 24.000.000.

Evaluasi dari kegiatan pengabdian masyarakat ini adalah kelompok tani Tani Mulya sudah berhasil memproduksi bunga dan biji TSS namun jumlahnya masih rendah. Penyebab masih rendahnya produksi TSS mungkin disebabkan karena teknologi ini masih pertama kali mereka lakukan, sehingga petani perlu adaptasi untuk mengadopsi teknologi TSS dan sekaligus perlu mempelajari dari berbagai sumber bagaimana cara meningkatkan produksi biji TSS dan memperbesar ukuran umbi bawang merah yang berasal dari benih TSS.

Diharapkan setelah kegiatan pengabdian masyarakarat yang mono tahun ini, petani tetap terus melanjutkan produksi benih TSS dan menggunakan umbi mini dari TSS sebagai benih bawang merah yang bermutu dan sehat. Oleh karena itu, pemantauan dan pendampingan petani bawang merah Desa Tawangargo untuk memproduksi benih TSS dan umbi mini perlu sinergi antara tim pengabdian masyarat, petani dan lembaga pemerintah desa setempat sebagai salah satu program prioriotas desa dengan dana desa setempat.

\section{SIMPULAN}

Kegiatan pengabdian masyarakat ini telah berhasil dilaksanakan dan mampu menghasilkan benih TSS dari varietas lokal Batu Ijo meskipun jumlah tanaman berbunga masih 55,5\% dan bobot biji TSS $10,16 \mathrm{~g} / \mathrm{m}^{2}$ dan ini masih tergolong rendah dibandingkan hasil penelitian lain. Masih perlu kajian upaya meningkatkan persentase pembungaan dan jumlah umbel per tanaman sehingga diperoleh biji yang lebih banyak. Benih yang berasal TSS dari varietas Tri Sula dan Keta Monca juga dapat tumbuh dengan baik dan menghasilkan umbi mini sebagai benih tanaman bawang merah. Penggunaan benih TSS lebih menguntungkan secara ekonomi karena biaya benih sangat murah dibandingkan dengan benih dari umbi. Diharapkan kegiatan ini tetap dilanjutkan oleh petani Desa Tawangargo dibantu pendampingan oleh tim pengabdian masyarakat UPN Veteran Jawa Timur dengan bantuan dana desa dari lembaga desa sebagai salah satu program prioritas kegiatan Desa Tawangargo, yaitu program mengoptimalkan produksi TSS berupa bantuan teknis dan bahan produksi, supaya program produksi benih TSS dapat maksimal dan dapat mensejahterakan masyarakat petani di Desa Tawangargo, Kecamatan Karangploso, Kabupaten Malang.

\section{UCAPAN TERIMA KASIH}

Ucapan terima kasih disampaikan kepada LPPM UPN "Veteran" Jawa Timur yang telah mendanai kegiatan pengabdian masyarakat ini melalui skim RISMA (Penerapan Riset bagi Masyarakat).

\section{DAFTAR PUSTAKA}

Baswarsiati. 2009. Bawang Merah Batu Ijo Sayuran Spesifik Kota Batu. [Internet]. [Diunduh 2018 Februari 19]. Tersedia pada: https://baswarsiati.wordpress.com/2009/04 /24/bawang-merah-batu-ijo-sayuranspesifik-kota-batu/.

Harian Surya Malang. 2017. Hasil Panen Bawang Merah di Kabupaten Malang. [Internet]. [Diunduh 2018 Februari 19]. Tersedia pada: http://suryamalang.tribunnews.com/2017/0 9/21/hasil-panen-bawang-merah-dikabupaten-malang-lebihi-perkiraanperhatikan-jenis-benihnya

Idhan A, Syam'un E, Zakaria B, Riyadi M. 2015. Potential Selection of Flowering and Tuber Production in Fourteen Onion Varieties (Allium ascalonicum L.) at Lowland and Upland. International Journal of Current Research in Biosciences and Plant Biology. 2 (7): 63-67.

Litbang Pertanian. 2015. Kelangkaan Bawang Merah, Solusinya Ada di Biji Bawang. 
[Diunduh 2018 Februari 20].Tersedia pada: http://www.litbang.pertanian.go.id/berita/o ne/2091/.

Moeljani IR. 2015. Rekayasa Lingkungan Untuk Meningkatkan Pembungaan Dan Fertilitas produksi Biji TSS (True Seed of Shallot) Bawang Merah (Allium sativum L). [Disertasi]. Surabaya [ID]. Universitas Airlangga. 142 halaman.

Palupi ER, Manik F, Suhartanto MR. 2017. Can We Produce True Seed Of Shallot (TSS) From Small Size Shallot Sets? Journal of Tropical Crop Science. 4 (1): 26-31.

Prahardini PER, Sudaryono T. 2018. The True Seed of Shalott (TSS) Technology Production on Trisula Variety in East Java. Jurnal Pembangunan dan Alam Lestari. 9(1): 27-32. https://doi.org/10.21776/ub.jpal.2018.009.0 1.05

Prayudi B, Pangestuti R, Kusumasari AC. 2015. Produksi Umbi Mini Bawang Merah Asal True Seed of Shallot (TSS). Dalam: Inovasi Hortikutura Pengungkit Peningkatan Pendapatan Rakyat. Jakarta (ID): IAARD Press. Halaman: 35-44.
Pusat Data Informasi Pertanian. 2015. Out Look Komoditas Pertanian Sub Sektor Hortikultura Bawang Merah. Jakarta (ID): Kementerian Pertanian. 104 halaman.

Pusat Penelitian dan Pengembangan Hortikultura. 2016. Balitbangtan serius mengembangkan TSS, benih biji bawang merah. [Diunduh 2019 April 9]. Tersedia pada: http://hortikultura.litbang.pertanian.go.id/b erita-786-balitbangtan-seriusmengembangkan-tss-benih-biji-bawangmerah.html.

Sumarni N, Suwandi, Gunaeni N, Putrasamedja S. 2013. Pengaruh Varietas dan Cara Aplikasi $\mathrm{GA}_{3}$ terhadap Pembungaan dan Hasil Biji Bawang Merah Dataran Tinggi Sulawesi Selatan. Jurnal Hortikultura. 23(2): 153-163. https://doi.org/10.21082/jhort.v23n2.2013. p153-163

Suwandi, 2013. Teknologi Perbenihan Bawang Merah melalui TSS (True Seed of Shalot). Badan Litbang Pertanian [Internet]. [Diunduh 2019 Februari 4]. Tersedia pada: http://www.hortikultura.litbang.pertanian.g o.id. 